\title{
Ozone Pollution: A Major Health Hazard Worldwide
}

\author{
Junfeng (Jim) Zhang ${ }^{1,2,3 *}$, Yongjie Wei ${ }^{4,5 *}$ and Zhangfu Fang ${ }^{3}$ \\ ${ }^{1}$ Nicholas School of the Environment and Duke Global Health Institute, Duke University, Durham, NC, United States, ${ }^{2}$ Global \\ Health Research Center, Duke Kunshan University, Kunshan, China, ${ }^{3}$ Guangzhou Institute of Respiratory Health, Guangzhou \\ Medical University, Guangzhou, China, ${ }^{4}$ State Key Laboratory of Environmental Criteria and Risk Assessment \& \\ Environmental Standards Institute, Chinese Research Academy of Environmental Sciences, Beijing, China, ${ }^{5}$ Center for Global \\ Health, School of Public Health, Nanjing Medical University, Nanjing, China
}

\section{OPEN ACCESS}

Edited by:

Bernahrd Ryffel,

Centre National de la Recherche

Scientifique (CNRS), France

Reviewed by:

Juerg Hamacher,

Lindenhofspital, Switzerland

Manoussa Ethel Fanny,

Boston Children's Hospital, Harvard

Medical School, United States

François Erard

University of Orléans, France

${ }^{*}$ Correspondence:

Junfeng (Jim) Zhang

junfeng.zhang@duke.edu

Yongjie Wei

weiyj@craes.org.cn

Specialty section: This article was submitted to

Inflammation,

a section of the journal

Frontiers in Immunology

Received: 20 August 2019 Accepted: 09 October 2019

Published: 31 October 2019

Citation:

Zhang J, Wei Y and Fang Z (2019) Ozone Pollution: A Major Health Hazard Worldwide.

Front. Immunol. 10:2518 doi: 10.3389/fimmu.2019.02518
Oxides of nitrogen $\left(\mathrm{NO}_{\mathrm{x}}\right)$ and volatile organic compounds (VOCs) released into the atmosphere can react in the presence of solar irradiation, leading to ozone formation in the troposphere. Historically, before clean air regulations were implemented to control $\mathrm{NO}_{x}$ and VOCs, ozone concentrations were high enough to exert acute effects such as eye and nose irritation, respiratory disease emergencies, and lung function impairment. At or above current regulatory standards, day-to-day variations in ozone concentrations have been positively associated with asthma incidence and daily non-accidental mortality rate. Emerging evidence has shown that both short-term and long-term exposures to ozone, at concentrations below the current regulatory standards, were associated with increased mortality due to respiratory and cardiovascular diseases. The pathophysiology to support the epidemiologic associations between mortality and morbidity and ozone centers at the chemical and toxicological property of ozone as a strong oxidant, being able to induce oxidative damages to cells and the lining fluids of the airways, and immune-inflammatory responses within and beyond the lung. These new findings add substantially to the existing challenges in controlling ozone pollution. For example, in the United States in 2016, 90\% of non-compliance to the national ambient air quality standards was due to ozone whereas only $10 \%$ was due to particulate matter and other regulated pollutants. Climate change, through creating atmospheric conditions favoring ozone formation, has been and will continue to increase ozone concentrations in many parts of world. Worldwide, ozone is responsible for several hundreds of thousands of premature deaths and tens of millions of asthma-related emergency room visits annually. To combat ozone pollution globally, more aggressive reductions in fossil fuel consumption are needed to cut $\mathrm{NO}_{\mathrm{x}}$ and VOCs as well as greenhouse gas emissions. Meanwhile, preventive and therapeutic strategies are needed to alleviate the detrimental effects of ozone especially in more susceptible individuals. Interventional trials in humans are needed to evaluate the efficacy of antioxidants and ozone-scavenging compounds that have shown promising results in animal studies.

Keywords: ozone, climate change, air quality standards, cardiovascular health effects, respiratory health effects, mitigation strategies 


\section{SOURCES AND CHEMISTRY}

Ozone, the triplet oxygen $\left(\mathrm{O}_{3}\right)$, is formed from the reaction between dioxygen $\left(\mathrm{O}_{2}\right.$, the normal oxygen molecule) and a singlet oxygen $(\mathrm{O}$, oxygen atom) in the presence of a third-body molecule able to absorb the heat of the reaction. The highly reactive and short-lived singlet oxygen $(\mathrm{O})$ can be generated via the photolysis of nitrogen dioxide $\left(\mathrm{NO}_{2}\right)$ or ionization of $\mathrm{O}_{2}$. Background ozone is present in both the stratosphere and the troposphere. Stratospheric ozone is concentrated in the tropopause ( $\sim$ between 8 and $15 \mathrm{~km}$ above the ground), a region that is called ozone layer. Stratospheric ozone is nicknamed "good" ozone, because the ozone layer plays a vital role in absorbing ultraviolet (UV-B) rays that are harmful to living beings on the earth. Since direct contact with ozone at the ground level can cause damages to living cells, organs, and species including humans, animals, and plants, tropospheric or ground-level ozone is nicknamed "bad" ozone.

There is a natural influx of ozone from the stratosphere to the troposphere, peaking normally in the spring months when the vertical air movement reaches its maximum in the northern hemisphere. This influx contributes to background levels of ground-level ozone. The predominant source of tropospheric ozone, however, is the photochemical reactions involving volatile organic compounds (VOCs) and oxides of nitrogen $\left(\mathrm{NO}_{\mathrm{x}}\right)$, mainly comprised of $\mathrm{NO}_{2}$ and nitric oxide (NO). In the absence of or at very low concentrations of VOCs or carbon monoxide (CO), ozone reaches a steady-state concentration depending on solar intensity, ambient temperature, and the ratio of $\mathrm{NO}_{2}$ concentration to $\mathrm{NO}$ concentration. Under this condition, one $\mathrm{NO}_{2}$ molecule is converted via photolysis into one $\mathrm{O}_{3}$ molecule and one NO molecule; and ozone is, in turn, consumed by NO to regenerate a $\mathrm{NO}_{2}$ molecule. This cycle results in zero accumulation of ozone concentration. However, VOCs or CO participate in a series of complex photochemical reactions to produce free radicals that compete with ozone to react with NO. The net effects include the accumulation of ozone, the oxidation of VOCs into oxygenated organic compounds, and the formation of nitrogen-containing compound, and the oxidation of $\mathrm{CO}$ into $\mathrm{CO}_{2}$. Because many of the oxygenated and nitrogencontaining organic compounds are present in the condensed phase due to their low volatility, they are called secondary organic aerosols (SOAs). The whole mixture composed of ozone, SOAs, and their gaseous precursors is called photochemical smog. The production of ozone in the troposphere is depicted in Figure 1.

This ozone formation mechanism (Figure 1) explains why elevated ozone concentrations are found in an increasing number of places around the world where anthropogenic emissions of $\mathrm{NO}_{\mathrm{x}}$, VOCs, and $\mathrm{CO}$ have been increasing. The combustion of fossil fuels occurs at a high temperature favorable for $\mathrm{NO}_{\mathrm{x}}$ formation, and worldwide increases in fossil-fuel derived energy (for electricity generation, transportation, and household cooking and heating) are responsible for increasing emissions of $\mathrm{NO}_{\mathrm{x}}$. Major anthropogenic sources of VOCs include vehicular exhaust, fugitive evaporation of gasoline and other gaseous fuels (e.g., natural gas and propane), biomass and fossil fuel combustion, and industrial solvent use. A recent study found

\section{Formation of Ground-Level Ozone}

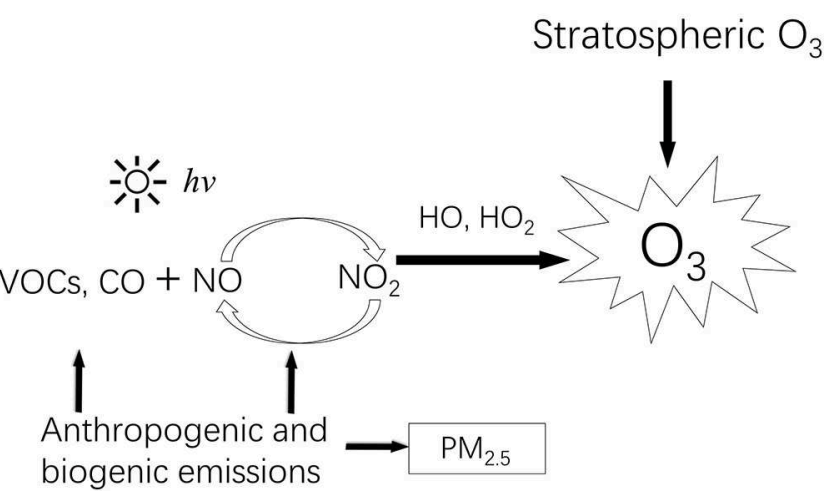

FIGURE 1 | Ozone in the stratosphere can move downward to the troposphere, contributing to the "background" level of ground-level ozone. However, high levels of ozone in the troposphere are due to photochemical reactions involving volatile organic compounds (VOCs) and oxides of nitrogen $\left(\mathrm{NO}_{\mathrm{x}}\right.$ : $\mathrm{NO}$, and $\mathrm{NO}_{2}$ ). Anthropogenic emissions (e.g., fossil fuel combustion) are responsible for $\mathrm{NO}_{x}$ and mainly responsible for VOCs and CO. Trees also emit certain VOCs (e.g., isoprene). $\mathrm{PM}_{2.5}$ from primary emission sources can react with (consume) free radicals (e.g., $\mathrm{HO}_{2}$ ) responsible for ozone formation, which partly explains the observations in certain areas where ozone level increased while $\mathrm{PM}_{2.5}$ level decreased. $h v$, photon; VOCs, volatile organic compounds; $\mathrm{CO}$, carbon monoxide; $\mathrm{NO}$, nitric oxide; $\mathrm{NO}_{2}$, nitrogen dioxide; $\mathrm{NO}_{x}, \mathrm{NO}$ and $\mathrm{NO}_{2} ; \mathrm{HO}$, the hydroxyl radical; $\mathrm{HO}_{2}$, The hydroperoxy radical; $\mathrm{PM}_{2.5}$, Particulate matter with a diameter of $2.5 \mu \mathrm{m}$ or less.

that volatile chemicals released from consumer products (e.g., pesticides, coatings, printing inks, adhesives, cleaning agents, and personal care products) have emerged as a large urban source of VOCs (1). Natural vegetation emissions of certain VOCs (e.g., isoprene) also contribute to ozone formation especially at the regional scale (2-5).

Ozone formation depends on solar intensity that is directly associated with atmospheric temperature. Ironically, with a decrease in ambient concentrations of carbonaceous aerosols (e.g., soot), emitted from combustion of coal, diesel, and biomass, atmospheric visibility increases, and consequently solar intensity increases, favoring ozone formation. More importantly, particulate matter (e.g., particles with an aerodynamic diameter equal to or smaller than $2.5 \mu \mathrm{m}$, noted as $\mathrm{PM}_{2.5}$ ) can serve as a sink of free radicals responsible for ozone formation. A recent study showed that a 40\% reduction in $\mathrm{PM}_{2.5}$ from 2013 to 2017 in the North China Plain was partly responsible for an increasing ozone trend (at 1-3 ppb per year) during the period of 2013-2017 observed in megacity clusters of eastern China (6).

\section{IMPACT OF CLIMATE CHANGE ON GROUND-LEVEL OZONE}

Ozone itself is a greenhouse gas in the atmosphere. Hence, increasing ground-level ozone contributes to global warming. On the other hand, a warming climate favors the formation and accumulation of ozone in the atmosphere mainly through 
two physicochemical mechanisms. First, in certain parts of the world, a warming climate changes humidity and wind conditions, leading to decreases in the frequency of surface cyclones. The resulting more stagnant atmospheric condition decreases the dispersion of $\mathrm{NO}_{\mathrm{x}}$ and VOCs and prolongs the time for the reactions to produce ozone. Second, ozone-forming reactions are typically enhanced by increased atmospheric temperatures. Based on these climate-induced changes in the atmospheric stability (air stagnation) and temperature, it is predicted that by the year 2050, warming alone may increase by $68 \%$ the number of ozone-standard exceedance days across the eastern United States (7). Another study predicted that changes in regional climate and globally enhanced ozone would increase ground-level ozone over most of the United States. More specially, it is predicted that the 95 th percentile for daily 8 -h maximum ozone would increase from 79 ppb in 2012 to 87 ppb in 2050 (8). Similarly, another predictive analysis, through integrating data from climate model outputs and historical meteorology and ozone observations across 19 urban communities in southeastern United States, estimated an increase of $0.43 \mathrm{ppb}$ (95\% CI: 0.14-0.75) in average ozone concentration during the 2040s compared to 2000 due to climate change alone (9).

Climate change can also prolong the ozone season. For example, high ozone concentrations usually occur in the summer in the United States. However, ozone during the fall reached the summer level in several Octobers in the 2000s and in 2010 over the southeastern United States. This was attributed to enhanced emissions of biogenic isoprene (a VOC precursor of ozone) from water-stressed plants under a drying and warming condition (10). This finding suggests that occurrences of a drying and warming fall in the future may lead to an extension of the ozone season from summer to fall in the regions with significant biogenic VOC emissions.

\section{AMBIENT CONCENTRATIONS IN REFERENCE OF AIR QUALITY STANDARDS}

Ozone is in gas phase under typical atmospheric conditions (temperature and pressure) and is commonly measured as mixing ratio, i.e., parts per million ( $\mathrm{ppm}$ ) or parts per billion (ppb). At the standard conditions for temperature $\left(25^{\circ} \mathrm{C}\right)$ and pressure (1 atmosphere), $1 \mathrm{ppb}$ ozone equals $1.97 \mu \mathrm{g} / \mathrm{m}^{3}$. Based on its commonly recognized health effects, including causing breathing problems, triggering asthma attacks, reducing lung function, and increasing incidence of respiratory diseases, ozone is one of the regulated air pollutants in many countries and has a recommended limit by the World Health Organization (WHO). The current WHO Air Quality Guidelines for ambient (outdoor) ozone is $100 \mu \mathrm{g} / \mathrm{m}^{3}$ ( $\sim 50 \mathrm{ppb}$ ) measured as 8 -h maximum moving average within a day ${ }^{1}$. In the United States, the current National Ambient Air Quality Standards (NAAQS) for ozone include a 1 -h standard (1-h maximum within a day)

${ }^{1}$ https://www.who.int/news-room/fact-sheets/detail/ambient-(outdoor)-airquality-and-health at $120 \mathrm{ppb}$ and an 8 -h standard (8-h daily max) at $70 \mathrm{ppb}$. The rationales for having two standards with different averaging times are as follows.

Historically, the NAAQS only had a 1-h standard, as a sharp peak of ozone concentration typically lasted for $1 \mathrm{~h}$ or a bit longer during the afternoon and evening hours in Los Angeles, California, and other large cities. This peak concentration was high enough to cause acute effects such as irritation to the eyes and the respiratory tract, lung function reduction, difficulty to breathe, and increased emergency room visits. However, this feature does not occur in most areas of the United States, because the regional transport of ozone precursors prolonged the hours of elevated ozone concentrations. Epidemiological studies have found that ozone concentrations averaged over a longer period (such as $8 \mathrm{~h}$ instead of $1 \mathrm{~h}$ ) within a day are a more health-relevant indicator of ozone exposure. In fact, as of June 15, 2005, the 1$\mathrm{h}$ ozone standard is no longer applied to areas designated with respect to the 8 -h ozone standard, which includes most of the United States, except for portions of 10 states $^{2}$.

Since the enaction of the U.S. Clean Air Act Amendment in 1970, remarkable efforts were made to control the emissions of the two ozone precursors (and other criteria pollutants). From 1980 to 2017, total national emissions of $\mathrm{NO}_{\mathrm{X}}$ and VOCs were reduced by 61 and 54\%, respectively. Consequently, there was a $32 \%$ decrease in national average of daily maximum 8 $\mathrm{h}$ averages of ozone measured at 200 monitoring sites across the United States ${ }^{3}$. Despite this nationwide decrease and more drastic decrease in some ozone "hot spots" such as Los Angeles and Atlanta, Georgia ${ }^{4,5}, 100.6$ million people nationwide (or nearly one in every three people) lived in U.S. counties where ozone levels exceeded the NAAQS standard of 70 ppb in 2017 (In contrast, much fewer people, 58 million in total lived in counties where $\mathrm{PM}_{2.5}, \mathrm{PM}_{10}, \mathrm{SO}_{2}$, or lead exceeded the NAAQS) ${ }^{3}$. If the WHO-recommended 8-h limit of $50 \mathrm{ppb}$ is used, there would be even more people living in places with ozone exceeding the health-based limit.

Although ambient ozone concentrations have showed a declining trend in the United States and similarly in Western Europe and Japan in the past decades ${ }^{6}$, evidence suggests that global average ozone concentrations are increasing. For example, ozone measured at Mt Waliguan Observatory (a global "background" site) on the Tibetan Plateau over the period of 1994-2013 has shown an increasing trend at 0.2-0.3 ppb per year during spring and autumn (11). The springtime ozone increase was partly $(\sim 60 \%)$ attributed to increased stratosphereto-troposphere transport, whereas rising Asian anthropogenic emissions of ozone precursors were the key driver of increasing autumnal ozone at this site. This finding is alarming, because ozone is generally considered too reactive to be transported afar. However, this demonstrates that $\mathrm{NO}_{\mathrm{x}}$ and VOCs emitted in more

\footnotetext{
${ }^{2}$ https://www.epa.gov/criteria-air-pollutants/naaqs-table

${ }^{3}$ https://www.epa.gov/air-trends/ozone-trends

${ }^{4}$ https://calepa.ca.gov/

${ }^{5}$ https://www.epa.gov/ga

${ }^{6}$ http://www.futureearth.org/blog/2018-feb-5/powerful-new-dataset-revealspatterns-global-ozone-pollution
} 
populous regions can undergo long-range transport and affect "background" ozone level. More importantly, this finding also suggests an increasing ozone trend not only in places where $\mathrm{NO}_{\mathrm{x}}$ and VOCs were originally emitted but also along the air trajectories from precursor sources to the background site.

Although the air quality focus has been on particulate matter, especially $\mathrm{PM}_{2.5}$, in rapidly developing economies such as China and India in the recent years, the "invisible" ozone pollution is increasingly recognized as a major health hazard. While annual $\mathrm{PM}_{2.5}$ average concentrations showed a decreasing trend in many cities of China (12), ground-level ozone concentrations measured in some monitoring sites in China showed an increasing trend in the past several years. For example, observations made at a rural site (Dadianzi) $100 \mathrm{~km}$ northeast Beijing showed a steady increase in annual averages of the 8-h daily max ozone concentrations from 2004 to 2015 (13). Consistently, a recent analysis of ground-level ozone concentrations measured at nearly 1,000 sites across China also found an increasing trend of summertime ozone in northeastern China from 2013 to 2017 (6). This increase was attributed to changes in anthropogenic emissions of ozone precursors as well as reductions in $\mathrm{PM}_{2.5}$ concentrations as described earlier. Due to the strong governmental efforts to primarily control $\mathrm{PM}_{2.5}$ in China, anthropogenic emissions of $\mathrm{NO}_{\mathrm{x}}$ have decreased substantially in most urban areas of China (a $21 \%$ nationwide reduction) from 2013 to 2017 (6). However, VOC emissions have remained relatively unchanged. Typically decreasing $\mathrm{NO}_{\mathrm{x}}$ would increase ozone under VOC-limited conditions, which has been the case for many urban areas of China. All these explain that in summer months, daily air quality reports released to the public in recent years have often shown more days when the ozone standard was exceeded than when $\mathrm{PM}_{2.5}$ or other regulated pollutants exceeded the standards in many cities of China. This trend in China appears to follow the pattern of the United States where non-compliance to ozone standard has been more frequently observed in more places than that to $\mathrm{PM}_{2.5}$ or other pollutants.

\section{HUMAN EXPOSURE AND DOSIMETRY}

It is the fundamental principle of toxicology that "dose makes poison." It is common in air pollution epidemiologic studies to use ambient concentrations as a proxy for exposure or, more strictly speaking, dose. This approach omits interand intra-person differences in breathing rate and does not consider concentration differences between indoor and outdoor environments. Among common or the criteria pollutants defined by the US EPA, ozone has unique characteristics that can lead to substantial errors for using ambient ozone concentration as a proxy for dose.

First, ozone is chemically reactive and can be more effectively scavenged by building surfaces. In airtight buildings with doors and windows closed, indoor ozone levels are typically smaller than $20 \%$ of outdoor levels. In contrast, for leaky buildings and for building with windows frequently open, indoor concentrations can reach $>70 \%$ outdoor concentrations. Because typically people spend the majority of time indoors, using outdoor concentration as a surrogate for ozone exposure would lead to greater overestimation of exposure for people living or working in more airtight buildings than for those living in less airtight buildings. This systematic exposure assessment error was used to explain a difference in ozone effect estimates in U.S populations living in buildings with different indoor-outdoor air exchange rates ${ }^{1}$. Recent advancement in small and low-cost ozone sensors makes personal monitoring or indoor monitoring more affordable and feasible. More accurate ozone monitoring can be used in future studies of ozone epidemiology and can also aid data-based personal prevention actions.

Second, outdoor ozone concentrations exhibit a substantial seasonal variation in most of the places. This adds challenges to assess the health effect of long-term exposure in epidemiological studies. Unlike using annual averages for other pollutants such as $\mathrm{PM}_{2.5}$, warm-season averages have often been used $(14,15)$, assuming that the health risk associated with lowerlevel ozone in cold months is negligible. Accordingly, certain ozone control policies have been implemented only during photochemical smog months. In the United States, for example, gasoline is formulated with higher oxygen content (typically with increased fraction of ethanol) in warmer months to reduce VOC emissions that contribute to ozone formation. However, accumulating evidence suggests that there may not exist a threshold ozone concentration below which the risk is "zero." Therefore, completely ignoring cold months in ozone control strategy may need to be revisited.

Third, outdoor ozone typically exhibits a distinct diurnal pattern with high concentrations during afternoon and early evening hours. Hourly concentrations of ozone are usually reported at ambient monitoring stations. For regulatory purposes, these hourly data are computed as moving averages to identify maximum 1 - and 8-h concentrations (based on moving averages) within a day. In epidemiological studies, using concentrations with different averaging times has different toxicological assumptions. Using 1-h max concentration is to assess the acute effect of peak exposure, whereas using 8-h daily max concentration assumes that lower concentrations during the rest of $16 \mathrm{~h}$ do not contribute to an adverse effect. It is also possible that either 1 - or 8 -h $\max$ concentrations were simply used due to the data availability in previous epidemiologic studies of short-term ozone effects (16-20). In addressing exposure to low-level concentrations (such as concentrations below the current air quality standard), however, 24-h average may be another relevant measure of daily exposure, at least for certain outcomes (21-24).

\section{HEALTH EFFECTS EVIDENCE TO SUPPORT OZONE REGULATIONS}

Following a formal process of an extensive literature review and a critical analysis, the US EPA summarized its evaluation of available evidence in the 2013 US EPA Integrated Science Assessment for Ozone ${ }^{7}$. Based on this assessment, the national ambient air quality standard for 8-h daily max ozone was revised from 75 to $70 \mathrm{ppb}$ in 2015 . The health effects evidence used to

\footnotetext{
${ }^{7}$ https://cfpub.epa.gov/ncea/isa/recordisplay.cfm?deid=247492
} 
support these revisions include mainly the following, which has been well-demonstrated in recent reviews $(25,26)$.

- Ozone can cause adverse respiratory effects such as difficulty of breathing (e.g., shortness of breath and pain when taking a deep breath) and inflammation of the airways in the general population. These effects can aggravate lung diseases such as asthma, emphysema, and chronic bronchitis [chronic obstructive pulmonary disease (COPD)].

- Long-term exposure to ozone is likely to be one of many causes of asthma development.

- Ozone exposure is likely to cause premature deaths, and the evidence is stronger for mortality due to respiratory illnesses than for that due to other diseases.

- Children are at increased risk from ozone exposure, as children have a relatively higher dose per body mass and children's lung is still developing.

Does this revised standard imply that the effects listed above would not occur when 8-h daily max ozone concentrations are below $70 \mathrm{ppb}$ ? Although from a regulatory standard point, the public may be informed that it is "safe" to breathe the air when air quality meets the standards, it is easy to see that the standards are set somewhat arbitrary. For example, the WHO guideline for 8-h daily max ozone of $100 \mu \mathrm{g} / \mathrm{m}^{3}$ ( $\sim 50 \mathrm{ppb}$ ) is lower than the EPA standard, but the evidence to support this lower limit is similar to that in supporting a higher limit by the US EPA, with additional effects presented by the WHO as follows ${ }^{1}$ :

- Ozone can cause coughing and sore or scratchy throat.

- Ozone exposure makes the lungs more susceptible to infection.

- Ozone continues to damage the lungs even when the symptoms have disappeared.

Although WHO also considers that ozone is a cause of COPD, this evidence was not strong enough in the 2013 EPA integrated science assessment. Other effects of ozone reported include the following. On high ozone days, there have been increased school absences, increased visits to emergency rooms, and increased hospital admissions (27-30). Long-term exposures to ozone have been associated with lower lung function and deteriorated or abnormal lung development in children (31, 32). In both the WHO guideline and the EPA ozone standard, more susceptible populations are considered. In addition to people with preexisting respiratory diseases such as asthma and COPD, children, older adults, and people who are active outdoors (especially outdoor workers) are more vulnerable to ozone exposure.

\section{IMMUNE-INFLAMMATORY RESPONSES AND EMERGING EFFECTS}

As a potent oxidizing gas, ambient ozone is well-known to cause oxidative damages to the cells and the lining fluids of the airways, thereby inducing immune-inflammatory responses in the lung. Recent findings have shown that innate immunity is implicated in ozone-induced airway inflammation, such as the involvement of innate lymphoid cells (ILCs) in mice $(33,34)$. Ozone exposure contributes to the increased expression of mRNA of tumor necrosis factor- $\alpha$ (TNF- $\alpha$ ), interleukin-1 $\beta$ (IL-1 $\beta$ ), interleukin-6 (IL-6), and interleukin-8 (IL-8) in human alveolar macrophages (35) and increased concentrations of IL-6, IL-8, and fibrinogenic proteins in human airway epithelial cells (36). A seminal work by Koren et al. demonstrated that an acute exposure to ozone $(0.4$ ppm for $2 \mathrm{~h}$ ) resulted in 8.2-fold increase of polymorphonuclear leukocytes (PMN) in bronchial alveolar lavage (BAL) fluid and enhanced level of inflammatory mediators in the lower airways of humans (37). Krishna et al. further confirmed that ozone-induced neutrophil influx in human peripheral airways was partly mediated by IL-8 (38). Ozone exposure resulted in significant neutrophilic inflammation, reflected with increased levels of myeloperoxidase (MPO) in the supernatant of induced sputum samples from healthy subjects $(39,40)$.

These immune-inflammatory responses to ozone may "spill over" to the circulatory system, which may help explain emerging evidence on the cardiovascular and neuronal effects of ozone. Since the 2013 EPA assessment was released, several studies conducted in North America further confirmed significant positive associations, robust to controlling for co-pollutants, between short-term ozone exposure and one or more of the following mortality classifications: cardiovascular, dysrhythmia, cardiometabolic, and ischemic heart disease. A meta-analysis of 53 studies showed a weak but significant association between ozone and hospital admission and mortality from stroke (41). Significant associations of ozone were found with ischemic stroke occurrence in Seoul (42) and with non-myocardial infarction out-of-hospital cardiac arrests in Helsinki (43). Although Jerrett et al. (44) in the original analysis of an American Cancer Society cohort found that ozone exposure was associated with respiratory but not cardiovascular mortality, in the followup study using the same cohort, Turner et al. (14) found a significant association of long-term exposure to ozone with cardiovascular mortality. A recent cohort study by Lim et al. further confirmed this association between long-term exposure to ozone and increased cardiovascular mortality (45). However, there have also been epidemiological studies reporting null findings between long-term ozone exposure and cardiovascular mortality in Europe $(46,47)$.

Initiated in the lung, the immune-inflammatory responses to ozone may ultimately contribute to increased cardiovascular mortality and morbidity via two major pathways affecting hemostasis and autonomic tone. Increased exposure to ambient ozone has been associated with increased levels of hemostatic markers, including fibrinogen (48-50), von Willebrand factor (49), and plasminogen activator inhibitor-1 (48). Xia et al. revealed that short-term exposure to ambient ozone can elevate serum levels of ACE and ET-1, decrease their DNA methylation, and alter the lipid metabolism, which may be partly responsible for increased blood pressure and vascular endothelial disfunction (51). Day et al. found that an increase in 24-h or 2-week average exposure to ozone was associated with increased p-selectin (a soluble plasma marker of platelet activation), suggesting that ozone exposure increases the risk of thrombosis (21). Wang et al. found that increased ambient ozone exposure was associated with increased rate of carotid wall thickness progression and risk of 
new plaque formation in healthy adults (52). Jia et al. showed that ambient ozone exposure within several minutes can decrease heart rate variability in the healthy elderly subjects, suggesting that a dysfunction of cardiac autonomic nervous system may be involved (53). In controlled human exposure studies, a few hours of ozone exposure resulted in changes in markers of inflammation and fibrinolysis at $300 \mathrm{ppb}$ and changes in cardiac autonomic function at $110-300 \mathrm{ppb}(54,55)$. Although one study found a blunting of exercise-induced blood pressure increases (56) and another found increased systolic blood pressure in response to ozone exposure (57), other such studies found increases in diastolic blood pressure to a co-exposure of ozone and concentrated ambient PM but not to ozone alone (58, 59). In contrast, animal studies with high ozone exposures have generated more consistent findings on cardiovascular effects of ozone through altering vascular tone (60-62), mRNA for genes encoding thrombogenic factors (63), and atherogenesis (60).

Additionally, deleterious effects of ozone exposure on the central nervous system (CNS) are emerging (64, 65). Neurodegenerative disorders, such as Alzheimer's disease (AD) and Parkinson's disease, have been linked to ozone exposures in recent epidemiologic studies $(66,67)$. The following toxicological studies in rodents have demonstrated the CNS effects of ozone, shedding light on biological mechanisms to support the link between ozone exposure and outcomes related to CNS. Rodríguez et al. showed that ozone exposure resulted in the activation of apoptotic death in rat hippocampus mediated by endoplasmic reticulum stress (68). Bello-Medina et al. found that rats chronically exposed to ozone exhibited deficits in learning and memory loss associated with deafferentation in hippocampus-related neurons (69). Chronic exposure to low-dose ozone, on the other hand, could enhance systemic and hippocampal Th17/IL-17A immune responses, which may be partly responsible for neurodegenerative effects in rats (70).

\section{DISCUSSION AND CONCLUSIONS}

Ozone pollution is a worldwide health hazard. In many parts of the world, as described above, ozone concentrations are projected to increase, leading to increases in ozone-associated mortalities and morbidities. A study reported a $6 \%$ increase in premature deaths attributable to ozone globally from 1990 to 2010 (71), although the estimates (143,000 deaths in 1990 and 152,000 deaths in 2010) seem to be substantially lower than the estimated reported in other studies. In one study, for example, anthropogenic ozone was associated with an estimated 700,000 $\pm 300,000$ respiratory mortalities in 2000 (72). In another study, exposure to ozone was responsible for 254,000 deaths from COPD alone in 2015 (73). Other ozone-associated mortality estimates include 316,000 respiratory deaths in China (15) and $\sim 23,500$ in the European Union ${ }^{8}$. The relatively large gap in the estimates across studies is due to uncertainties associated with and inconsistence in concentration-effect relationship and ozone exposure assessment. These estimates were based on respiratory

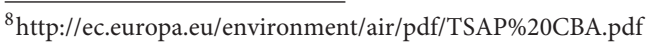

effects alone, due to uncertainties associated with the current evidence on the cardiovascular effects. It is expected that the impact would be larger when other ozone effects were considered.

Ozone exposure was associated with large morbidity estimates. An estimated 9-23 million (8-20\% of total) asthmarelated emergency room visits globally were attributable to ozone (74). A large multicity study in China showed that shortterm exposure to ambient ozone was associated with higher non-accidental and cardiovascular mortality (20). In addition, an estimated 23.0-40.3 million respiratory-related deaths were attributable to long-term $\mathrm{O}_{3}$ exposure in 2016 (15). In the European Union, ozone in 2010 was responsible for 19,200 cases of respiratory hospital admissions, 86,000 cases of cardiovascular hospital admissions, and over 109,000,000 minor restricted activity days ${ }^{7}$. Disability adjust life years (DALY) lost attributable to ozone were estimated to be $6.3 \pm 3.0$ million years in 2000 (58) and 4.1 (95\% CI: 1.6-6.8) million years from COPD alone in 2015 (73).

Disease burden attributable to ozone is expected to continue to rise in the future for two reasons. The first is the fact that ozone concentration is on the rise in many parts of the world as described earlier. For example, an estimated increase of 0.43 $\mathrm{ppb}$ in average ozone concentration, during the 2040s compared to 2000 due to climate change alone, would correspond to a $0.01 \%$ increase in mortality rate in 19 urban communities in southeastern United States (9). Relative to that in 2000, there will be a $14 \%$ increase in global ozone-related mortality (75). The second is anticipated improvement in our understanding of the ozone effects beyond the lung and improved characterization of the chronic effects of long-term exposure. The improved knowledge will likely add to ozone-associated disease burden that is currently uncounted for.

There remain significant challenges in ascertaining chronic ozone exposure and effects that are currently inconclusive. Epidemiological evidence is limited to support a causal relationship between the chronic exposure and mortality or morbidity, although progresses have been made in recent years by using large datasets. For example, an analysis of national databases found a positive association between increase in long-term ozone concentrations and an increased risk of respiratory diseases and death (44). Di et al. (76) analyzed the entire US Medicare population of 60 million older adults from the years 2000 through 2012 and found a positive association between annual averages of ozone and all-cause mortality rate. Using large hospital records, increased chronic ozone exposure was associated with increased asthma hospital admissions in children (27). Long-term ozone exposure (3year averages) has been associated with development of acute respiratory distress syndrome (ARDS) in at-risk critically ill patients, particularly in trauma patients and current smokers (77). By examining life expectancy at birth in 3,109 counties of the conterminous U.S. during 2002 to 2008 in relation to county-specific mean levels and rates of change in ozone concentrations, a study found that a $5 \mathrm{ppb}\left(10 \mu \mathrm{g} / \mathrm{m}^{3}\right)$ increase in long-term ozone concentration was associated with 0.25 year ( $95 \% \mathrm{CI}$ : -0.30 to -0.19 ) lower life expectancy in males and 0.21 year $(95 \% \mathrm{CI}:-0.25$ to -0.17$)$ in females (78). 
One of the challenges is to determine what is the best measure for long-term ozone exposure, given that ozone has distinct diurnal, and seasonal variations. A relevant question is whether repeated episodes of short-term high-level exposures can result in lasting health effects beyond the observed acute effects. Answering this question is not easy as some of the acute ozone effects are known to be reversible. What remains unknown is how much of the acute effects can be repaired or reversed between the episodes. At the meantime, people are constantly exposed to other air pollutants such as $\mathrm{PM}_{2.5}$. The co-exposure may affect the ability to repair the damage caused by acute ozone exposures. The natural fluctuation in ambient ozone concentration hence makes it challenging to examine chronic effects of short-term and long-term exposures. However, it is imperative to address such challenges in future studies of novel study design incorporating promising technologies in monitoring and computing ozone exposures with unprecedented accuracy and precision.

The large disease burden resulting from ozone pollution warrants persistent calls for control polices worldwide, but this is more urgent in developing countries where most of the attention is paid toward $\mathrm{PM}_{2.5}$ reductions. Based on the history of ozone control in the United States, aggregative regulatory actions to cut down anthropogenic emissions of $\mathrm{NO}_{\mathrm{x}}$ and VOCs have not necessarily resulted in sufficient reductions in ozone concentrations in certain areas of the United States. Part of the challenges is the "non-linear" relationship of ozone production with its precursors, as reducing one of the precursors may not necessarily lead to ozone reduction. Even within a metropolitan area, the optimal ratio of $\mathrm{NO}_{\mathrm{x}}$ to VOCs associated with minimal ozone formation changes from day to day (even hour to hour) and from upwind to downwind. Sources of VOCs can be numerous and hard to characterize. Some known sources, such as household use of consumer chemicals and biogenic emissions, are difficult to control through regulatory actions. Although the fundamental chemistry of ozone formation is clear, ozone concentrations, and spatiotemporal distributions are specific to local meteorological conditions, local sources of $\mathrm{NO}_{\mathrm{x}}$ and VOCs, and long-range transport of ozone and associated chemical species. For all these challenges, ozone pollution in developing countries is expected to be a long-term problem, and local and national polices should be developed or strengthened to persistently combat ozone pollution.

In the United States and developed countries with relatively better air quality, following decades of controls for $\mathrm{NO}_{\mathrm{x}}$ and VOCs emissions, further controls of anthropogenic emissions via policy, and technological tools are becoming increasingly limited. Meanwhile, predictions of ozone levels in response to changing $\mathrm{NO}_{\mathrm{x}}$ and VOC concentrations get harder with ozone concentrations approaching their "background" level. Yet, emerging evidence does not support a threshold for adverse effects of ozone $(79,80)$. Or if a threshold exists, it would have to be substantially lower than the current health-based regulatory standards or guidelines.

Considering all these challenges, it is imperative to use other means to reduce the health impact of ozone. During high ozone hours, the public, especially children and those with preexisting health problems, is advised to avoid outdoor activities. Schools may be advised to cancel outdoor sports activities. Because indoor ozone levels are a small fraction of outdoor levels in airtight buildings with door/windows closed, this strategy can effectively reduce individuals' exposure to ozone. To further reduce outdoor exposure, individuals may consider wearing a face mask that can effectively scavenge ozone. Face masks rated $\mathrm{N} 95$ or higher can filter out $\mathrm{PM}_{2.5}$ effectively and are widely available in the market worldwide. However, few models of face masks are designed to remove ozone. Making ozone forecasting available to the general public will enhance the effectiveness of such personal protection methods to reduce ozone exposure (81).

A wealth of data from animal studies and human studies are available in the literature to help understand pathophysiologic mechanisms by which ozone affects the lung. Relatively less is known to understand how ozone affects the cardiovascular health outcomes, although the immune-inflammatory responses initiated in the lung are thought to be the key in more downstream systemic effects. The mechanistic understanding appears to be sufficient to support the use of antioxidants or ozone scavenger to alleviate the ozone effects. For example, rodent studies confirmed that the use of $\mathrm{N}$-acetylcysteine and sulfide salt can help prevent or recover the lung impairment caused by ozone $(82,83)$. Limited studies in humans have shown promising results. A randomized trial found that a daily supplement of vitamins $\mathrm{C}$ and $\mathrm{E}$ might provide some protection against acute nasal inflammatory response to ozone in asthmatic children (84). In a control human exposure study (2-h exposure to $400 \mathrm{ppb}$ ozone vs. filtered air), healthy adults who had received a dietary antioxidant supplementation of a mixture of vitamin $\mathrm{C}$, alpha-tocopherol, and vegetable cocktail exhibited a significantly smaller ozone-induced reduction in pulmonary function (85). Cohort and population-based interventional trials should be conducted in real-world settings to develop more targeted preventive or therapeutic strategies especially in vulnerable populations and individuals. This should be part of the overall strategy, along with air pollution control polices, to combat ozone pollution, a lasting worldwide health hazard.

\section{AUTHOR CONTRIBUTIONS}

JZ and YW: conception. JZ, YW, and ZF: drafting the manuscript, editing and revising the manuscript. All authors gave final approval for publishing.

\section{ACKNOWLEDGMENTS}

JZ wishes to thank Dr. Drew Day for compiling the evidence related to cardiovascular effects of ozone exposure, as part of his Ph.D. dissertation research at Duke University Nicholas School of the Environment, partly supported by Grant 51420105010 from the National Natural Science Foundation of China. 


\section{REFERENCES}

1. McDonald BC, de Gouw JA, Gilman JB, Jathar SH, Akherati A, Cappa CD, et al. Volatile chemical products emerging as largest petrochemical source of urban organic emissions. Science. (2018) 359:760-4. doi: 10.1126/science.aaq0524

2. Fehsenfeld F, Calvert J, Fall R, Goldan P, Guenther AB, Hewitt CN, et al. Emissions of volatile organic compounds from vegetation and the implications for atmospheric chemistry. Glob Biogeochem Cycles. (1992) 6:389-430. doi: 10.1029/92GB02125

3. Guenther A, Geron C, Pierce T, Lamb B, Harley P, Fall R. Natural emissions of non-methane volatile organic compounds, carbon monoxide, and oxides of nitrogen from North America. Atmosph Environ. (2000) 34:2205-30. doi: 10.1016/\$1352-2310(99)00465-3

4. Calfapietra C, Fares S, Loreto F. Volatile organic compounds from Italian vegetation and their interaction with ozone. Environ Pollut. (2009) 157:147886. doi: 10.1016/j.envpol.2008.09.048

5. Calfapietra C, Fares S, Manes F, Morani A, Sgrigna G, Loreto F. Role of Biogenic Volatile Organic Compounds (BVOC) emitted by urban trees on ozone concentration in cities: a review. Environ Pollut. (2013) 183:7180. doi: 10.1016/j.envpol.2013.03.012

6. Li K, Jacob DJ, Liao H, Shen L, Zhang Q, Bates KH. Anthropogenic drivers of 2013-2017 trends in summer surface ozone in China. Proc Natl Acad Sci USA. (2019) 116:422-7. doi: 10.1073/pnas.1812168116

7. Bell ML, Goldberg R, Hogrefe C, Kinney PL, Knowlton K, Lynn B, et al. Climate change, ambient ozone, and health in 50 US cities. Clim Change. (2007) 82:61-76. doi: 10.1007/s10584-006-9166-7

8. Pfister G, Walters S, Lamarque JF, Fast J, Barth M, Wong J, et al. Projections of future summertime ozone over the US. JGR: atmospheres (2014) 119:555982. doi: 10.1002/2013JD020932

9. Chang HH, Zhou J, Fuentes M. Impact of climate change on ambient ozone level and mortality in southeastern United States. Int J Environ Res Public Health. (2010) 7:2866-80. doi: 10.3390/ijerph7072866

10. Zhang Y, Wang Y. Climate-driven ground-level ozone extreme in the fall over the Southeast United States. Proc Natl Acad Sci USA. (2016) 113:1002530. doi: $10.1073 /$ pnas. 1602563113

11. Xu W, Xu X, Lin M, Lin W, Tarasick D, Tang J, et al. Long-term trends of surface ozone and its influencing factors at the Mt Waliguan GAW station, China-Part 2: the roles of anthropogenic emissions and climate variability. Atmos Chem Phys. (2018) 18:773-98. doi: 10.5194/acp-18-773-2018

12. Ma Z, Hu X, Sayer AM, Levy R, Zhang Q, Xue Y, et al. Satellite-based spatiotemporal trends in PM2. 5 concentrations: China, 2004-2013. Environ Health Perspect. (2015) 124:184-92. doi: 10.1289/ehp.1409481

13. Ma Z, Xu J, Quan W, Zhang Z, Lin W, Xu X. Significant increase of surface ozone at a rural site, north of eastern China. Atmos Chem Phys. (2016) 16:3969-77. doi: 10.5194/acp-16-3969-2016

14. Turner MC, Jerrett M, Pope III CA, Krewski D, Gapstur SM, Diver WR, et al. Long-term ozone exposure and mortality in a large prospective study. Am J Respir Crit Care Med. (2016) 193:1134-42. doi: 10.1164/rccm.201508-1633OC

15. Malley CS, Henze DK, Kuylenstierna JCI, Vallack HW, Davila Y, Anenberg SC, et al. Updated global estimates of respiratory mortality in adults $>/=30$ years of age attributable to long-term ozone exposure. Environ Health Perspect. (2017) 125:087021. doi: 10.1289/EHP1390

16. Strosnider HM, Chang HH, Darrow LA, Liu Y, Vaidyanathan A, Strickland $\mathrm{MJ}$. Age-specific associations of ozone and $\mathrm{PM}_{2.5}$ with respiratory emergency department visits in the US. Am J Respir Crit Care Med. (2019) 199:882-90. doi: $10.1164 / \mathrm{rccm} .201806-1147 \mathrm{OC}$

17. Lin M, Chen Y, Villeneuve PJ, Burnett RT, Lemyre L, Hertzman C, et al. Gaseous air pollutants and asthma hospitalization of children with low household income in Vancouver, British Columbia, Canada. Am J Epidemiol. (2004) 159:294-303. doi: 10.1093/aje/kwh043

18. Neidell M, Kinney PL. Estimates of the association between ozone and asthma hospitalizations that account for behavioral responses to air quality information. Environ Sci Policy. (2010) 13:97-103. doi: 10.1016/j.envsci.2009.12.006

19. Nhung NTT, Schindler C, Dien TM, Probst-Hensch N, Perez L, Kunzli N. Acute effects of ambient air pollution on lower respiratory infections in
Hanoi children: an eight-year time series study. Environ Int. (2018) 110:13948. doi: 10.1016/j.envint.2017.10.024

20. Yin P, Chen R, Wang L, Meng X, Liu C, Niu Y, et al. Ambient ozone pollution and daily mortality: a nationwide study in 272 Chinese cities. Environ Health Perspect. (2017) 125:117006. doi: 10.1289/EHP1849

21. Day D, Xiang J, Mo J, Li F, Chung M, Gong J, et al. Association of ozone exposure with cardiorespiratory pathophysiologic mechanisms in healthy adults. JAMA Intern Med. (2017) 177:1344-53. doi: 10.1001/jamainternmed.2017.2842

22. Di Q, Dai L, Wang Y, Zanobetti A, Choirat C, Schwartz JD, et al. Association of short-term exposure to air pollution with mortality in older adults. JAMA. (2017) 318:2446-56. doi: 10.1001/jama.2017.17923

23. Dai Y, Qiu H, Sun S, Yang Y, Lin H, Tian L. Age-dependent effect of ambient ozone on emergency asthma hospitalizations in Hong Kong. J Allergy Clin Immunol. (2018) 141:1532-4.e5. doi: 10.1016/j.jaci.2018.01.006

24. Sun Q, Wang W, Chen C, Ban J, Xu D, Zhu P, et al. Acute effect of multiple ozone metrics on mortality by season in 34 Chinese counties in 2013-2015. J Intern Med. (2018) 283:481-8. doi: 10.1111/joim.12724

25. Nuvolone D, Petri D, Voller F. The effects of ozone on human health. Environ Sci Pollut Res. (2018) 25:8074-88. doi: 10.1007/s11356-017-9239-3

26. Koman PD, Mancuso P. Ozone exposure, cardiopulmonary health, and obesity: a substantive review. Chem Res Toxicol. (2017) 30:1384-95. doi: 10.1021/acs.chemrestox.7b00077

27. Lin S, Liu X, Le LH, Hwang SA. Chronic exposure to ambient ozone and asthma hospital admissions among children. Environ Health Perspect. (2008) 116:1725-30. doi: 10.1289/ehp.11184

28. Strickland MJ1, Darrow LA, Klein M, Flanders WD, Sarnat JA, Waller LA, et al. Short-term associations between ambient air pollutants and pediatric asthma emergency department visits. Am J Respir Crit Care Med. (2010) 182:307-16. doi: 10.1164/rccm.200908-1201OC

29. Malig BJ, Pearson DL, Chang YB, Broadwin R, Basu R, Green RS, et al. A timestratified case-crossover study of ambient ozone exposure and emergency department visits for specific respiratory diagnoses in California (2005-2008). Environ Health Perspect. (2016) 124:745-53. doi: 10.1289/ehp.1409495

30. Tian Y, Liu H, Zhao Z, Xiang X, Li M, Juan J, et al. Association between ambient air pollution and daily hospital admissions for ischemic stroke: a nationwide time-series analysis. PLoS Med. (2018) 15:e1002668. doi: 10.1371/journal.pmed.1002668

31. Gauderman WJ, Avol E, Gilliland F, Vora H, Thomas D, Berhane K, et al. The effect of air pollution on lung development from 10 to 18 years of age. $N$ Engl J Med. (2004) 351:1057-67. doi: 10.1056/NEJMoa040610

32. Gauderman WJ, Gilliland GF, Vora H, Avol E, Stram D, McConnell R, et al. Association between air pollution and lung function growth in southern California children: results from a second cohort. Am J Respir Crit Care Med. (2002) 166:76-84. doi: $10.1164 /$ rccm.2111021

33. Kumagai K, Lewandowski RP, Jackson-Humbles DN, Buglak N, Li N, White $\mathrm{K}$, et al. Innate lymphoid cells mediate pulmonary eosinophilic inflammation, airway mucous cell metaplasia, and type 2 immunity in mice exposed to ozone. Toxicol pathol. (2017) 45:692-704. doi: 10.1177/0192623317728135

34. Yang Q, Ge MQ, Kokalari B, Redai IG, Wang X, Kemeny DM, et al. Group 2 innate lymphoid cells mediate ozone-induced airway inflammation and hyperresponsiveness in mice. J Allergy Clin Immunol. (2016) 137:5718. doi: 10.1016/j.jaci.2015.06.037

35. Arsalane K, Gosset P, Vanhee D, Voisin C, Hamid Q, Tonnel AB, et al. Ozone stimulates synthesis of inflammatory cytokines by alveolar macrophages in vitro. Am J Respir Cell Mol Biol. (1995) 13:60-8. doi: 10.1165/ajrcmb.13.1.7598938

36. Devlin R, McKinnon K, Noah T, Becker S, Koren H. Ozone-induced release of cytokines and fibronectin by alveolar macrophages and airway epithelial cells. Am J Physiol. (1994) 266:L612-9. doi: 10.1152/ajplung.1994.266.6.L612

37. Koren HS, Devlin RB, Graham DE, Mann R, McGee MP, Horstman DH, et al. Ozone-induced inflammation in the lower airways of human subjects. Am Rev Respir Dis. (1989) 139:407-15. doi: 10.1164/ajrccm/139.2.407

38. Krishna MT, Madden J, Teran LM, Biscione GL, Lau LC, Withers NJ, et al. Effects of $0.2 \mathrm{ppm}$ ozone on biomarkers of inflammation in bronchoalveolar lavage fluid and bronchial mucosa of healthy subjects. Eur Respir J. (1998) 11:1294. 
39. Fahy JV, Wong HH, Liu JT, Boushey HA. Analysis of induced sputum after air and ozone exposures in healthy subjects. Environ Res. (1995) 70:7783. doi: 10.1006/enrs.1995.1051

40. Holz O, Khalilieh S, Ludwig-Sengpiel A, Watz H, Stryszak P, Soni $\mathrm{P}$, et al. SCH527123, a novel CXCR2 antagonist, inhibits ozoneinduced neutrophilia in healthy subjects. Eur Respir J. (2010) 35:564-70. doi: 10.1183/09031936.00048509

41. Shah AS, Lee KK, McAllister DA, Hunter A, Nair H, Whiteley W, et al. Short term exposure to air pollution and stroke: systematic review and meta-analysis. BMJ. (2015) 350:h1295. doi: 10.1136/bmj.h1295

42. Han MH, Yi HJ, Kim YS, Ko Y, Kim YS. Association between Diurnal Variation of Ozone concentration and stroke occurrence: 24-hour time series study. PLoS ONE. (2016) 11:e0152433. doi: 10.1371/journal.pone.0152433

43. Rosenthal FS, Kuisma M, Lanki T, Hussein T, Boyd J, Halonen JI, et al. Association of ozone and particulate air pollution with out-of-hospital cardiac arrest in Helsinki, Finland: evidence for two different etiologies. J Expo Sci Environ Epidemiol. (2013) 23:281-8. doi: 10.1038/jes.2012.121

44. Jerrett M, Burnett RT, Pope III CA, Ito K, Thurston G, Krewski D, et al. Long-term ozone exposure and mortality. N Engl J Med. (2009) 360:108595. doi: 10.1056/NEJMoa0803894

45. Lim CC, Hayes RB, Ahn J, Shao Y, Silverman DT, Jones RR, et al. Long-term exposure to ozone and cause-specific mortality risk in the U.S. Am J Respir Crit Care Med. (2019) 200:1022-31. doi: 10.1164/rccm.201806-1161OC

46. Bentayeb M, Wagner V, Stempfelet M, Zins M, Goldberg M, Pascal $\mathrm{M}$, et al. Association between long-term exposure to air pollution and mortality in France: a 25-year follow-up study. Environ Int. (2015) 85:514. doi: 10.1016/j.envint.2015.08.006

47. Carey IM, Atkinson RW, Kent AJ, Van Staa T, Cook DG, Anderson HR. Mortality associations with long-term exposure to outdoor air pollution in a national English cohort. Am J Respir Crit Care Med. (2013) 187:122633. doi: 10.1164/rccm.201210-1758OC

48. Chuang KJ, Chan CC, Su TC, Lee CT, Tang CS. The effect of urban air pollution on inflammation, oxidative stress, coagulation, and autonomic dysfunction in young adults. Am J Respir Crit Care Med. (2007) 176:3706. doi: 10.1164/rccm.200611-1627OC

49. Liao D, Heiss G, Chinchilli VM, Duan Y, Folsom AR, Lin H-M, et al. Association of criteria pollutants with plasma hemostatic/inflammatory markers: a population-based study. J Expo Anal Environ Epidemiol. (2005) 15:319-28. doi: 10.1038/sj.jea.7500408

50. Steinvil A, Kordova-Biezuner L, Shapira I, Berliner S, Rogowski O. Short-term exposure to air pollution and inflammation-sensitive biomarkers. Environ Res. (2008) 106:51-61. doi: 10.1016/j.envres.2007.08.006

51. Xia Y, Niu Y, Cai J, Lin Z, Liu C, Li H, et al. Effects of personal shortterm exposure to ambient ozone on blood pressure and vascular endothelial function: a mechanistic study based on DNA methylation and metabolomics. Environ Sci Technol. (2018) 52:12774-82. doi: 10.1021/acs.est.8b03044

52. Wang M, Sampson PD, Sheppard LE, Stein JH, Vedal S, Kaufman JD. Long-term exposure to ambient ozone and progression of subclinical arterial disease: the multi-ethnic study of atherosclerosis and air pollution. Environ Health Perspect. (2019) 127:57001. doi: 10.1289/EHP3325

53. Jia X, Song X, Shima M, Tamura K, Deng F, Guo X. Acute effect of ambient ozone on heart rate variability in healthy elderly subjects. J Expo Sci Environ Epidemiol. (2011) 21:541-7. doi: 10.1038/jes.2011.18

54. Devlin RB, Duncan KE, Jardim M, Schmitt MT, Rappold AG, Diaz-Sanchez D. Controlled exposure of healthy young volunteers to ozone causes cardiovascular effects. Circulation. (2012) 126:104-11. doi: 10.1161/CIRCULATIONAHA.112.094359

55. Fakhri AA, Ilic LM, Wellenius GA, Urch B, Silverman F, Gold DR, et al. Autonomic effects of controlled fine particulate exposure in young healthy adults: effect modification by ozone. Environ Health Perspect. (2009) 117:1287-92. doi: 10.1289/ehp.0900541

56. Frampton MW, Pietropaoli A, Dentler M, Chalupa D, Little EL, Stewart J, et al. Cardiovascular effects of ozone in healthy subjects with and without deletion of glutathione-S-transferase M1. Inhal Toxicol. (2015) 27:1139. doi: 10.3109/08958378.2014.996272.

57. Sivagangabalan G, Spears D, Masse S, Urch B, Brook RD, Silverman F, et al. The effect of air pollution on spatial dispersion of myocardial repolarization in healthy human volunteers. J Am Coll Cardiol. (2011) 57:198206. doi: 10.1016/j.jacc.2010.08.625

58. Brook RD, Brook JR, Urch B, Vincent R, Rajagopalan S, Silverman F. Inhalation of fine particulate air pollution and ozone causes acute arterial vasoconstriction in healthy adults. Circulation. (2002) 105:15346. doi: 10.1161/01.CIR.0000013838.94747.64

59. Urch B, Silverman F, Corey P, Brook JR, Lukic KZ, Rajagopalan S, et al. Acute blood pressure responses in healthy adults during controlled air pollution exposures. Environ Health Perspect. (2005) 113:1052-5. doi: 10.1289/ehp.7785

60. Chuang GC, Yang Z, Westbrook DG, Pompilius M, Ballinger CA, White CR, et al. Pulmonary ozone exposure induces vascular dysfunction, mitochondrial damage, and atherogenesis. Am J Physiol Lung Cell Mol Physiol. (2009) 297:L209-16. doi: 10.1152/ajplung.00102.2009

61. Paffett ML, Zychowski KE, Sheppard L, Robertson S, Weaver JM, Lucas $\mathrm{SN}$, et al. Ozone inhalation impairs coronary artery dilation via intracellular oxidative stress: evidence for serum-borne factors as drivers of systemic toxicity. Toxicol Sci. (2015) 146:244-53. doi: 10.1093/toxsci/kfv093

62. Robertson S, Colombo ES, Lucas SN, Hall PR, Febbraio M, Paffett $\mathrm{ML}$, et al. CD36 mediates endothelial dysfunction downstream of circulating factors induced by O3 exposure. Toxicol Sci. (2013) 134:304-11. doi: 10.1093/toxsci/kft107

63. Kodavanti UP, Thomas R, Ledbetter AD, Schladweiler MC, Shannahan JH, Wallenborn JG, et al. Vascular and cardiac impairments in rats inhaling ozone and diesel exhaust particles. Environ Health Perspect. (2010) 119:3128. doi: $10.1289 /$ ehp. 1002386

64. Martínez-Lazcano JC, Gonzalez-Guevara E, del Carmen Rubio M, FrancoPerez J, Custodio V, Hernandez-Ceron M, et al. The effects of ozone exposure and associated injury mechanisms on the central nervous system. Rev Neurosci. (2013) 24:337-52. doi: 10.1515/revneuro-2012-0084

65. Croze ML, Zimmer L. Ozone atmospheric pollution and Alzheimer's disease: from epidemiological facts to molecular mechanisms. J Alzheimers Dis. (2018) 62:503-22. doi: 10.3233/JAD-170857.

66. Jung C-R, Lin Y-T, Hwang B-F. Ozone, particulate matter, and newly diagnosed Alzheimer's disease: a population-based cohort study in Taiwan. $J$ Alzheimers Dis. (2015) 44:573-84. doi: 10.3233/JAD-140855.

67. Kirrane EF, Bowman C, Davis JA, Hoppin JA, Blair A, Chen H, et al Associations of ozone and PM2. 5 concentrations with Parkinson's disease among participants in the agricultural health study. J Occup Environ Med. (2015) 57:509-17. doi: 10.1097/JOM.0000000000000451.

68. Rodriguez-Martinez E, Nava-Ruiz C, Escamilla-Chimal E, Borgonio-Perez G, Rivas-Arancibia S. The effect of chronic ozone exposure on the activation of endoplasmic reticulum stress and apoptosis in rat hippocampus. Front Aging Neurosci. (2016) 8:245. doi: 10.3389/fnagi.2016.00245.

69. Bello-Medina PC, Prado-Alcala RA, Rivas-Arancibia S. Effect of ozone exposure on dendritic spines of CA1 pyramidal neurons of the dorsal hippocampus and on object-place recognition memory in rats. Neuroscience. (2019) 402:1-10. doi: 10.1016/j.neuroscience.2019.01.018.

70. Solleiro-Villavicencio H, Rivas-Arancibia S. Systemic Th17/IL-17A response appears prior to hippocampal neurodegeneration in rats exposed to low doses of ozone. Neurología. (2019) 34:503-9. doi: 10.1016/j.nrleng.2019.03.003.

71. Lim SS, Vos T, Flaxman AD, Danaei G, Shibuya K, Adair-Rohani H, et al. A comparative risk assessment of burden of disease and injury attributable to 67 risk factors and risk factor clusters in 21 regions, 1990-2010: a systematic analysis for the Global Burden of Disease Study 2010. Lancet. (2012) 380:2224-60. doi: 10.1016/S0140-6736(12)61766-8

72. Anenberg SC, Horowitz LW, Tong DQ, West JJ. An estimate of the global burden of anthropogenic ozone and fine particulate matter on premature human mortality using atmospheric modeling. Environ Health Perspect. (2010) 118:1189-95. doi: 10.1289/ehp.0901220

73. Cohen AJ, Brauer M, Burnett R, Anderson HR, Frostad J, Estep K, et al. Estimates and 25-year trends of the global burden of disease attributable to ambient air pollution: an analysis of data from the Global Burden of Diseases Study 2015. Lancet. (2017) 389:1907-18. doi: 10.1016/S0140-6736(17)30505-6

74. Anenberg SC, Henze DK, Tinney V, Kinney PL, Raich W, Fann N, et al. Estimates of the global burden of ambient $\mathrm{PM}_{2.5}$, ozone, and $\mathrm{NO}_{2}$ on asthma incidence and emergency room visits. Environ Health Perspect. (2018) 126:107004. doi: 10.1289/EHP3766 
75. Silva RA, West JJ, Lamarque JF, Shindell DT, Collins WJ, Faluvegi G, et al. Future global mortality from changes in air pollution attributable to climate change. Nat Clim Change. (2017) 7:647-51. doi: 10.1038/nclimate3354

76. Di Q, Wang Y, Zanobetti A, Wang Y, Koutrakis P, Choirat C, et al. Air pollution and mortality in the Medicare population. N Engl J Med. (2017) 376:2513-22. doi: 10.1056/NEJMoa1702747

77. Ware LB, Zhao Z, Koyama T, May AK, Matthay MA, Lurmann FW, et al. Long-term ozone exposure increases the risk of developing the acute respiratory distress syndrome. Am J Respir Crit Care Med. (2016) 193:114350. doi: 10.1164/rccm.201507-1418OC

78. Li C, Balluz LS, Vaidyanathan A, Wen X-J, Hao Y, Qualters JR. Long-term exposure to ozone and life expectancy in the United States, 2002 to 2008. Medicine. (2016) 95:e2474. doi: 10.1097/MD.0000000000002474

79. Bell ML, Peng RD, Francesca D. The exposure-response curve for ozone and risk of mortality and the adequacy of current ozone regulations. Environ Health Perspect. (2006) 114:532-6. doi: 10.1289/ehp.8816

80. Chen K, Zhou L, Chen X, Bi J, Kinney PL. Acute effect of ozone exposure on daily mortality in seven cities of Jiangsu Province, China: no clear evidence for threshold. Environ Res. (2017) 155:235-41. doi: 10.1016/j.envres.2017.02.009

81. Zhang J. Low-level air pollution associated with death: policy and clinical implications. JAMA. (2017) 318:2431-2. doi: 10.1001/jama.2017.18948

82. Li F, Zhang P, Zhang M, Liang L, Sun X, Li M, et al. Hydrogen sulfide prevents and partially reverses ozone-induced features of lung inflammation and emphysema in mice. Am J Respir Cell Mol Biol. (2016) 55:7281. doi: $10.1165 / \mathrm{rcmb}$.2015-0014OC
83. Li F, Wiegman C, Seiffert JM, Zhu J, Clarke C, Chang Y, et al. Effects of $\mathrm{N}$-acetylcysteine in ozone-induced chronic obstructive pulmonary disease model. PLoS ONE. (2013) 8:e80782. doi: 10.1371/journal.pone. 0080782

84. Sienra-Monge JJ, Ramirez-Aguilar M, Moreno-Macias H, ReyesRuiz NI, Del Río-Navarro BE, Ruiz-Navarro MX, et al. Antioxidant supplementation and nasal inflammatory responses among young asthmatics exposed to high levels of ozone. Clin Exp Immunol. (2004) 138:317-22. doi: 10.1111/j.1365-2249.2004.02606.x

85. Samet JM, Hatch GE, Horstman D, Steck-Scott S, Arab L, Bromberg $\mathrm{PA}$, et al. Effect of antioxidant supplementation on ozone-induced lung injury in human subjects. Am J Respir Crit Care Med. (2001) 164:81925. doi: 10.1164/ajrccm.164.5.2008003

Conflict of Interest: The authors declare that the research was conducted in the absence of any commercial or financial relationships that could be construed as a potential conflict of interest.

Copyright (c) 2019 Zhang, Wei and Fang. This is an open-access article distributed under the terms of the Creative Commons Attribution License (CC BY). The use, distribution or reproduction in other forums is permitted, provided the original author(s) and the copyright owner(s) are credited and that the original publication in this journal is cited, in accordance with accepted academic practice. No use, distribution or reproduction is permitted which does not comply with these terms. 